\title{
DEVELOPING ENGLISH SUMMATIVE TEST BASED ON REVISED BLOOM'S TAXONOMY
}

\author{
AN ARTICLE \\ Submitted as Partial Fulfillment of the Requirements for the Degree of \\ Sarjana Pendidikan
}

By:

THERESIA MANALU

Registration Number : 2123121054

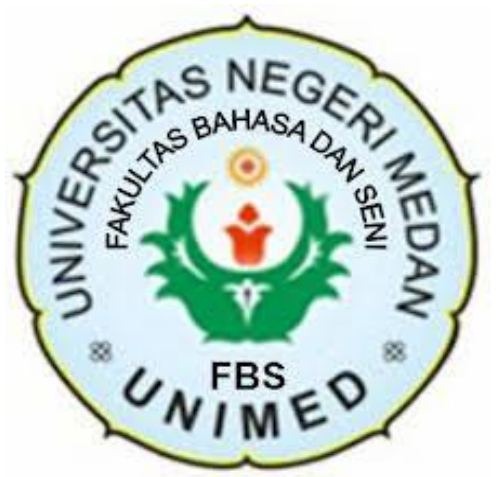

ENGLISH AND LITERATURE DEPARTMENT

FACULTY OF LANGUAGES AND ARTS STATE UNIVERSITY OF MEDAN 


\title{
ARTIKEL \\ DEVELOPING ENGLISH SUMMATIVE TEST BASED ON REVISED BLOOM'S TAXONOMY
}

\author{
Disusun dan Diajukan oleh:
}

Theresia Manalu

NIM. 2123121054

Telah diverifikasi dan dinyatakan memenuhi syarat untuk diunggah pada jurnal online

Medan, September 2016

Menyetujui

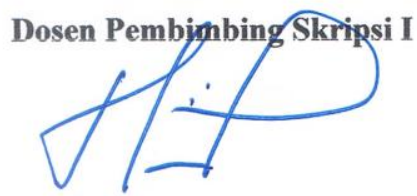

Dr. Siti Aisah Ginting, M.Pd NIP. 195705211984032002

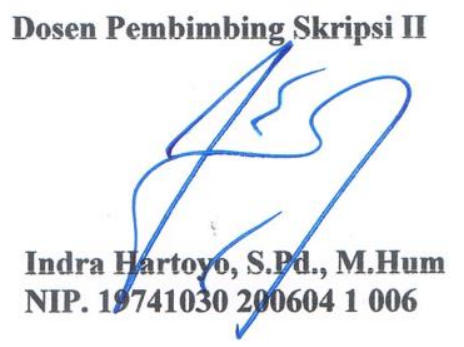

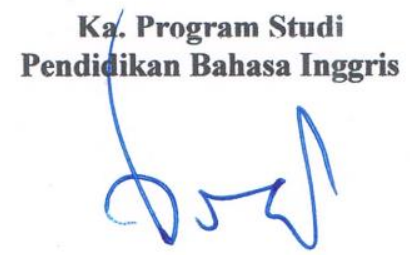

Nora Ronita Dewi, S.Pd., S.S., M.Hum.

NIP. 198005222008122003 


\title{
DEVELOPING ENGLISH SUMMATIVE TEST BASED ON \\ REVISED BLOOM'S TAXONOMY
}

*Theresia Manalu

**Siti Aisah Ginting

**Indra Hartoyo

\begin{abstract}
Manalu, Theresia. Registration Number: 2123121054. Developing English Summative Test based on Revised Bloom's Taxonomy. A Thesis. English Educational Program, State University of Medan, 2016.
\end{abstract}

This was a research and development (R\&D) study which aimed to evaluate the English summative test items based on revised Bloom's taxonomy for grade VIII. This study focused on the developing the English summative test items according to the cognitive level of revised Bloom's taxonomy for grade VIII at SMP Negeri 3 Tebing Tinggi. The data consist of the existing English summative test items which were directly collected from the English teacher due to analyze the proportion of cognitive level according to revised Bloom's taxonomy. Based on the data analysis, the existing English summative test had not fulfilled the proportion of cognitive level according to revised Bloom's taxonomy regulated by the Ministry of Education and Culture. The inappropriate English summative test items were then developed according to the proportion demand and suitability to the syllabus and indicators. The results of the study are 30 developed English summative test items which had been validated by the experts and tested to 20 students due to get the reliability scores.

Keywords: English summative test, revised Bloom's taxonomy, $R \& D$ research

*Graduate Status 


\section{INTRODUCTION}

\section{Background of the Study}

The information about students' achievement is very important in teaching and learning process. After collecting the information about students' achievement whether it is improved or not, teachers can evaluate the techniques and mediums in teaching, and can develop the appropriate materials and assessments in teaching. Therefore, conducting evaluation to every topic discussed in the classroom is one of the most important things of teachers' tasks. That is why teachers are demanded to be able to design a good quality test item. Moreover, Indonesian government applied the proportion for each level of education based on Bloom's Taxonomy is surely different based on the guidance for assessment which is regulated by the Ministry of Education and Culture. For Junior High School itself the proportion is remembering understanding 20\%, applying-analyzing 55\%, evaluating 15\%, and creating $10 \%$.

Considering the expectations described above, there are still English test items which do not fulfill the Government Regulation. Based on the preliminary data at SMP Negeri 3 Tebing Tinggi on Thursday, $10^{\text {th }}$ March 2016, it can be seen the spread of 29 ( 1 is error) multiple choice English questions for midterm test. From the observation which has been done, it shows that the English questions in mid-term examination which would be administered on March $28^{\text {th }}, 2016$ are mostly in remembering level. The percentage is $76 \%$, consist of 22 questions from 29 and almost the whole test is in this level. For the understanding and applying, the percentage is only $10 \%$ and $14 \%$, consist of only 3 and 4 questions. Meanwhile, the three less level, analyzing, evaluating, and creating are nothing. It can be concluded that this test is totally not appropriate to be tested because it is disposed to the one level. 
Considering the reality above, it is needed to develop a good test based on the proportion of revised Bloom's taxonomy in order to get the accurate information and to develop the students' competency.

\section{REVIEW OF LITERATURE}

To do an evaluation to the students, teachers have to focus on the standard and criteria of a good test which means a test is arranged started from the topic which is seen from the syllabus and acts as the national standard and guidance for teachers in designing as well as developing the elements in teaching and learning process and the indicators of assessing students' achievement. When the test has already fulfilled all the criteria regulated by the government, that is the proportion of revised Bloom's Taxonomy and the criteria of a good test which are valid and reliable, and match to the topic and indicator of learning, the more accurate the test in telling the students' achievement in a certain period. That is why teachers have to pay attention to those criteria especially the proportion of each level in revised Bloom's Taxonomy because the government has already regulated the rules as the guidance for the teachers in designing a test.

There are two kinds of test which are usually administered by the teachers and one of them is summative test. Summative test is designed at the end of a course or unit of instruction which concerns primarily with the extent to which the students have achieved the intended outcomes of the instruction. In complete, the summative test is given at the end of a period of instruction for the purpose of certifying mastery or assigning grades.

Therefore, revised Bloom's taxonomy is used as a parameter or standard in developing the cognitive level of summative test item arranged by the English teacher which then being matched to the topic and indicator at the syllabus and lesson plan of the English teacher so students' 
competency can be measured accurately appropriate to the learning indicators. The English summative test will be developed according to the revised Bloom's taxonomy, topic and learning indicator by using the development test theory adopted from Borg \& Gall theory due to its purpose which is to analyze and develop the English summative test arranged by the English teacher.

\section{RESEARCH METHODOLOGY AND FINDINGS}

\section{Methodology}

This research was conducted based on educational research and development (R \& D). R \& D is one of research designs aimed at developing and validating educational products, like curriculum, syllabus, textbooks, instructional media, modules, assessment instrument, etc. (Borg \& Gall, 2003). This study aimed at developing the English summative test for grade VIII at SMP Negeri 3 Tebing Tinggi which could be administered at schools by firstly evaluating the existing English summative test items and finally developing them according to the cognitive level of revised Bloom's taxonomy.

This research was applied in 7 main steps, namely 1) Defining the construct to be measured, 2) Defining the target population, 3) Reviewing related theories, 4) Developing the prototype of English summative test, 5) Evaluating the prototype, 6) Revising the test, 7) Collecting data on test validity and reliability. The result of this research was explained based on the procedures of the research

Techniques of Analyzing the Data 
The techniques in analyzing the data are staged as follows:

1. Gathering information about the existing English summative test by using observation. Observation was conducted in order to get the related or supplementary data. Those data were syllabus and lesson plan arranged by the English teacher.

2. Adjusting the English summative test items to the learning instructions which had been collected.

3. Developing the English summative test items. This stage is purposed to develop the appropriate test according to the proportion of cognitive level according to revised Bloom's taxonomy.

\section{Findings}

The English summative test consisted of 30 multiple choices questions. There were 30 learning indicators according to the basic competences. There were 6 basic competences consisted of 9 skills which had to be mastered by the students along the second semester. These competences were found from the syllabus. The syllabus was taken from the English teacher of Grade VIII at SMP Negeri 3 Tebing Tinggi when the observation was conducted in order to get the data. From these learning indicators which had covered the basic competences then the items of English summative test were developed. The English teacher's summative test items above were further analyzed based on the theories of Bloom's taxonomy suited to the proportion regulated by the Ministry of Education and Culture which have been previously described in Chapter II. The result of the analysis is shown in table 4.1 .

Table 4.1

Percentage of Level of Cognitive based on Revised Bloom's Taxonomy Teacher's Version 


\begin{tabular}{ccc}
\hline Level of Cognitive & Total of Questions & Percentage \\
\hline Creating & - & - \\
\hline Evaluating & 1 & $3 \%$ \\
\hline Analyzing & - & - \\
\hline Applying & - & $97 \%$ \\
\hline Understanding & 18 & \\
\hline Remembering & 11 & $\mathbf{1 0 0 \%}$ \\
\hline Total & $\mathbf{3 0}$ &
\end{tabular}

Government had regulated the proportion of assessment according to the Bloom's taxonomy specifically for schools which applied curriculum 2013. For rememberingunderstanding was $20 \%$, analyzing-applying $55 \%$, evaluating $15 \%$, and creating $10 \%$. With a total proportion of each level which was arranged by the English teacher; understandingremembering 97\%, evaluating 3\%, and for other levels were nothing, the complete description, remembering 11 questions, understanding 18 questions which accumulated be 29 questions, evaluating 1 questions, and for other levels were nothing, then it can be concluded that the test has not fulfilled the proportion of each cognitive level of revised Bloom's taxonomy. It can be taken one example of the items at the following explanation.

Last holiday I went to Paris. I visited museums and sat in public gardens. A friendly waiter taught me a few words of French ...........................

What was the first place the writer visited?

a. Museum

b. Public garden

c. His room

d. Post office

It is actually is not suitable to the topic and indicators. The topic is about Oral and written text which states and asks last action/ incident. The indicators are the students will be able to arrange random words to be cohesive sentence (sentence building) and the students will be able to write short and simple sentences based on context. The question above totally does not match to the indicator. Moreover, the question is only in remembering level. The question can be revised into evaluating level at the following example. 
Choose the correct answer from this random sentence.

Holiday- to- I- Paris- museums- visited- went- last- and-

The answer is...

a. Last Holiday I went to Paris and visited museums

b. Last holiday went to museums and visited Paris

c. Holiday I went to Paris and last visited museums

d. Last I went to Paris and Holiday visited museums

From the exemplary question from teacher's version, It proved that the existing English summative test items were not appropriate to the proportion of cognitive levels of revised Bloom's taxonomy which is regulated by the Ministry of Education and Culture. There should be test development which fulfilled the proportion demand conducted.

Then, the existing English summative test items were adjusted to the learning instructions; the basic competence which is in syllabus and indicator which was in lesson plan based on the documentary observation done at the first steps in test development. It was found that from the 30 test items there were some questions which were not suitable to the basic competences and indicators which had been arranged by the government and the teacher for grade VIII (Appendix B and C). From those findings described above, the English summative test items had to be developed which fulfilled the proportion of cognitive level of revised Bloom's taxonomy and related to the learning instructions (syllabus and lesson plan).

\section{CONCLUSION AND SUGGESTIONS}

\section{Conclusions}

After analyzing the data, the conclusion drawn is that the teacher's English summative test has not fulfilled the proportion of cognitive level of Bloom's taxonomy regulated by the Ministry of Education and Culture. Then, the 30 multiple choice English summative test items which were inappropriate were then developed into 30 recommended multiple choice English 
summative test items based on the theory of revised Bloom's taxonomy, the learning indicators, and also the criteria of a good test which had been fulfilled the proportion of revised Bloom's taxonomy regulated by the government in order to get the accurate information of the students' competence. The recommended English summative test items or the product were then validated by two experts, Prof. Amrin Saragih, M.A., Ph.D as the lecturer and Bambang Sarianto, S.Pd as the English teacher at SMP Negeri 3 Tebing Tinggi. After validating the product, the field testing held in order to take the reliability of the recommended English summative test items. It was concluded that the 30 recommended English summative test items as valid and reliable test items with no significant revisions.

\section{Suggestions}

In relation to the conclusions, some suggestions are presented as follows.

1. For the English teachers

The English teachers should pay attention to the government demand in arranging the English summative test items for students in order to get the accurate information of the students. The English summative test applied at the end of semester as the evaluation test of the students whether they have mastered all the competencies demand. That is why, the appropriate English summative test is important to be arranged by the teacher so that the students' competence can be evaluated accurately.

2. For other researchers

Hopefully, this research could inspire other researchers who wanted to conduct a further research related to the test development as the references. 


\section{REFERENCES}

Anderson \& Krathwohl. 2001. A Taxonomy for Learning, Teaching, and Assessing: A Revisio of Bloom's Taxonomy of Educational Objectives.

Bloom, Benjamin, et.al. 1956. Taxonomy of Educational Objectives: Classification of Educational Goals. Boston: Longman

Borg \& Gall. 1983. Educational Research: An Introduction. Boston: Pearson Education

Direktorat Pembinaan Sekolah Menengah Pertama. 2014. Panduan Penilaian Pencapaian Kompetensipeserta Didik Sekolah Menengah Pertama

Gronlund, Norman E. Constructing Achievement Test. New Jersey: Prentice Hall

Harjali. 2012. Evaluasi Pembelajaran Bahasa Inggris pada Sekolah Menengah Kejuruan. International Journal. e-ISSN: 2442-9651,p-ISSN: 1411-3031 12(2) 